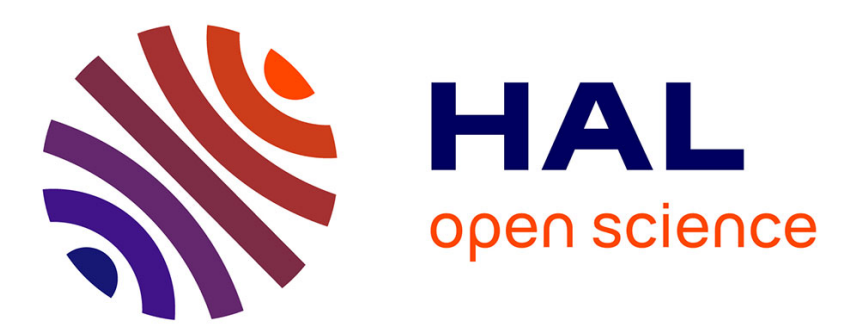

\title{
Energy and Nutrients Recovery from Lipid-Extracted Nannochloropsis via Anaerobic Digestion and Hydrothermal Liquefaction
}

M. Caporgno, E. Clavero, C. Torras, J. Salvado, O. Lepine, Jeremy Pruvost, J. Legrand, J. Giralt, C. Bengoa

\section{To cite this version:}

M. Caporgno, E. Clavero, C. Torras, J. Salvado, O. Lepine, et al.. Energy and Nutrients Recovery from Lipid-Extracted Nannochloropsis via Anaerobic Digestion and Hydrothermal Liquefaction. ACS Sustainable Chemistry \& Engineering, 2016, 4 (6), pp.3133-3139. 10.1021/acssuschemeng.6b00151 . hal-01950700

\section{HAL Id: hal-01950700 https://hal.science/hal-01950700}

Submitted on 20 Apr 2020

HAL is a multi-disciplinary open access archive for the deposit and dissemination of scientific research documents, whether they are published or not. The documents may come from teaching and research institutions in France or abroad, or from public or private research centers.
L'archive ouverte pluridisciplinaire HAL, est destinée au dépôt et à la diffusion de documents scientifiques de niveau recherche, publiés ou non, émanant des établissements d'enseignement et de recherche français ou étrangers, des laboratoires publics ou privés. 


\title{
Energy and Nutrients Recovery from Lipid-Extracted Nannochloropsis via Anaerobic Digestion and Hydrothermal Liquefaction
}

\author{
M. P. Caporgno, ${ }^{\dagger}$ E. Clavero, ${ }^{\ddagger}$ C. Torras, ${ }^{\ddagger}$ J. Salvadó $^{\dagger}{ }^{\dagger}$ O. Lepine, ${ }^{\S}$ J. Pruvost, $^{\prime \prime}$ J. Legrand, ${ }^{\|}$J. Giralt, $^{\dagger}$ \\ and C. Bengoa* ${ }^{\dagger}$ \\ ${ }^{\dagger}$ Departament d’Enginyeria Química, Universitat Rovira i Virgili, Av. Països Catalans 26, 43007 Tarragona, Spain \\ ${ }^{\ddagger}$ Bioenergy and Biofieuels Division, Catalonia Institute for Energy Research, IREC, C/Marcel-lí Domingo 2, 43007 Tarragona, Spain \\ ${ }^{\S}$ AlgoSource SAS, 37 bd de l'Université, CRTT-BP 406, 44602 Saint-Nazaire Cedex, France \\ "GEPEA, Université de Nantes, CNRS, UMR6144, bd de l’Université, CRTT-BP 406, 44602 Saint-Nazaire Cedex, France
}

ABSTRACT: The biomass, generated after the lipid extraction from Nannochloropsis microalgae (LEM) for biodiesel production, demonstrated its suitability for both energy and nutrient recovery. The anaerobic digestion of LEM produced a minimum of 268 $\mathrm{mL}_{\mathrm{CH} 4} / \mathrm{g}_{\mathrm{vs}}$ in different experiments. The codigestion of LEM and sewage sludge revealed that both wastes can be codigested without inhibition, although no synergy was observed. The methane yields barely increased $10 \%$ after pretreatments (ultrasound and ultrasound combined with alkali addition). Regarding bio-oil production from hydrothermal liquefaction process, more than $28 \%$ of the LEM was converted into bio-oil. Moreover, the aqueous phase generated during the bio-oil production was successfully utilized as nitrogen source for microalgae cultivation. KEYWORDS: Anaerobic codigestion, Anaerobic digestion, Cultivation, Hydrothermal liquefaction, Nutrients recovery, Pretreatments

Nannochloropsis gaditana

HTL Combustion

\section{INTRODUCTION}

Over the past years, researchers turned their attention to find renewable and cost-effective feedstocks for biofuels, as a consequence of the predicted fossil-fuel reserves depletion. Microalgae utilization as feedstock was also fostered by the "food-versus-fuel competition" derived from the biofuels production from crops. ${ }^{1}$ Among the different biofuels, biodiesel still gathers the attention of researchers. The process scale-up is not economically viable nowadays, ${ }^{2}$ but increasing efforts are being made to overcome the drawbacks. For example, the valorization of the lipid-extracted microalgae (LEM) may be beneficial for the biodiesel process. Approximately $65 \%$ of the biomass remains as waste after lipid extraction, containing some valuable compounds. ${ }^{3}$

The anaerobic digestion $(\mathrm{AD})$ is a well-known technology used for the stabilization of the sewage sludge generated in wastewater treatment plants (WWTPs). The versatility of this process allows the treatment of a wide range of feedstocks, including microalgae. In recent years, the LEM have been also considered as promising substrates for $\mathrm{AD} .^{3}$ The low $\mathrm{C}$ to $\mathrm{N}$ ratio in microalgae, which can lead to $\mathrm{AD}$ inhibition, is even lower in LEM. The anaerobic codigestion (Aco-D) with sewage sludge is a viable alternative to balance the $\mathrm{C}$ to $\mathrm{N}$ ratio. In addition to being widely available, sewage sludge is the second substrate utilized in codigestion due to the oversized digesters in WWTP. ${ }^{4}$ The $\mathrm{AD}$ also offers the advantage of recycling

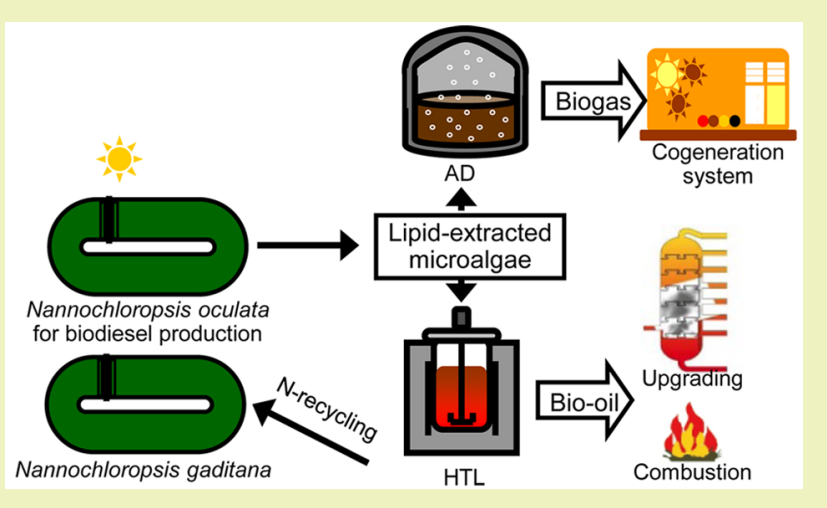

nutrient. The aqueous phase generated during $\mathrm{AD}$, rich in ammonia and phosphorus, may be used for microalgae cultivation. ${ }^{5,6}$ On the other hand, the hydrothermal liquefaction (HTL) is a completely different technology which converts microalgae and several microalgae waste into bio-oil. ${ }^{7-11}$ The bio-oil, a liquid fuel, can be further combusted or upgraded. Similar to $\mathrm{AD}$, the HTL process generates a nutrient-rich aqueous phase (AP-HTL) which can be recycled for microalgae cultivation. $^{12-14}$

This paper is the first attempt to evaluate several processing routes for the biofuel production from LEM; the routes can be observed in the scheme presented in Figure 1. Several options to avoid $\mathrm{AD}$ inhibition and to improve the methane production were evaluated. The increased protein content after the lipid extraction and the presence of sea salt in the LEM are potential causes of inhibition. ${ }^{3,15}$ The effects of high amounts of proteins were evaluated by setting several substrate to inoculum ratios (SIRs) in the experiments. Regarding sea salt, the influence of washing biomass was evaluated. The LEM were also codigested with sewage sludge, on the basis of the advantages of combining both substrates as previously mentioned. The last option consisted of applying two pretreatment methods to improve 


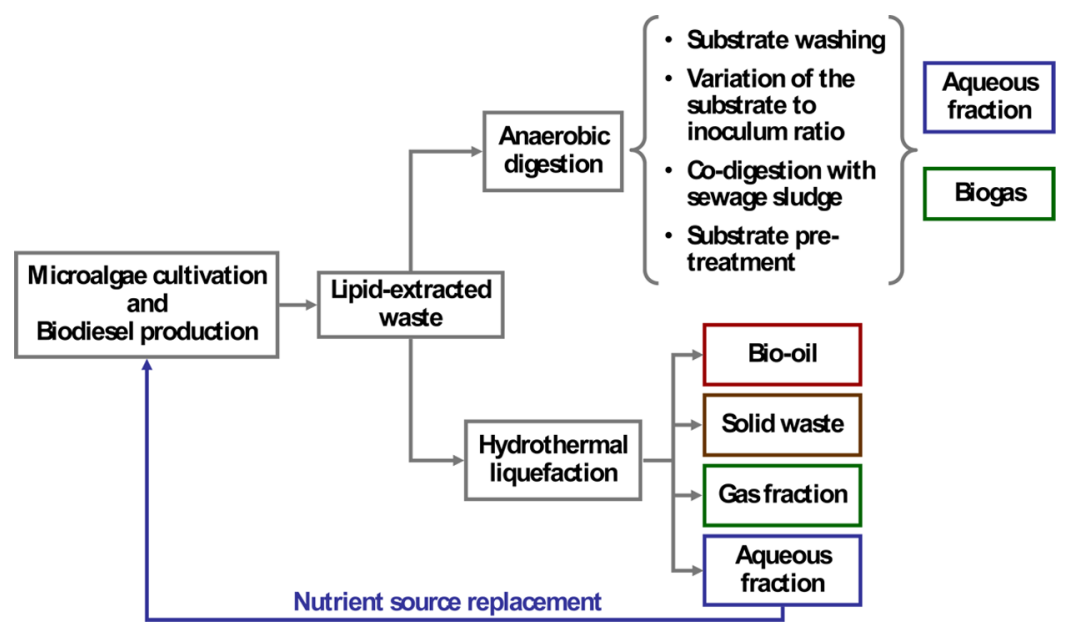

Figure 1. Scheme of the processing routes evaluated for the valorization of the LEM.

the methane production. The ultrasonic pretreatment was chosen on the basis of the suitability to increase the biodegradability of microalgae. ${ }^{16}$ The combination of alkali addition and ultrasonic pretreatment was chosen on the basis of the benefits when applied prior to the $\mathrm{AD}$ of some waste. ${ }^{17,18}$

In a completely different processing route, the LEM was used as for HTL. Although the process optimization is not addressed in this report, the valorization of the AP-HTL generated was evaluated as nutrient source for microalgae cultivation. The biooil production together with the nutrient recycling has not been reported yet.

\section{MATERIALS AND METHODS}

Materials. Lipid-extracted Nannochloropsis oculata, provided by AlgoSource (Alpha Biotech, Asserac, France), was generated from a lipid-extraction process with supercritical carbon dioxide $\left(\mathrm{SCCO}_{2}\right)$. The solid LEM was stored in a desiccator until required. The LEM was the substrate used for biofuels production via $\mathrm{AD}$ and HTL.

For the experiments where microalgae were cultivated in the aqueous phase recovered from the HTL, the species was Nannochloropsis gaditana Lubián, strain CCMP 1775, obtained from NCMA (National Center for Marine Algae), formerly CCMP.

The inoculum for the $\mathrm{AD}$ experiments consisted of digested sludge from a pilot-plant under mesophilic conditions. The reactors were operated under semicontinuous conditions and fed with a sewage sludge blend (primary and secondary sludge in ratio 65:35 v/v); the same sludge blend was utilized as substrate in the codigestion experiments. The sewage sludge blend was collected from the municipal WWTPs in Reus (Tarragona, Spain).

Experimental Procedure. Analytical Methods. Total solids (TS), volatile solids (VS), protein, and carbohydrate were analyzed according to the methods described in Caporgno et al. ${ }^{19}$ The residual lipid in the LEM was determined by extraction of $3 \mathrm{~g}$ of LEM using a Soxhlet apparatus with a reflux period of $7 \mathrm{~h}$ and hexane as solvent; lipids were then recovered by solvent evaporation and weighed. The TS content in the LEM was $928.8 \pm 0.7 \mathrm{~g} / \mathrm{kg}$, with VS/TS of $0.75 \pm$ 0.01 . The organic fraction contained $61.7 \pm 4.1 \%$ proteins, $7.6 \pm 0.1 \%$ lipids, and $25.3 \pm 2.0 \%$ carbohydrates. The TS content and the VS/TS were $27.8 \pm 0.7 \mathrm{~g} / \mathrm{L}$ and $0.76 \pm 0.01$ in sewage sludge, and $17.2 \pm 1.0$ $\mathrm{g} / \mathrm{L}$ and $0.64 \pm 0.02$ in the inoculum.

In the $\mathrm{AD}$ experiments, biogas production and composition, volatile fatty acid (VFA) concentration, and alkalinity were determined as described in Caporgno et al. ${ }^{19}$

In the HTL experiments, the bio-oil was analyzed by chromatography-mass spectroscopy (GC-MS). The samples were subjected to GS-MS analysis (G1099A/MSD5973) using a HP-5MS column (19091S-433) and helium as carrier gas with flow rate of $1.4 \mathrm{~mL} / \mathrm{min}$.
A volume of $1 \mu \mathrm{L}$ of dichloromethane (DCM) extract was injected at $280^{\circ} \mathrm{C}$ with a split ratio of $2: 1$. The initial temperature in the oven was $80{ }^{\circ} \mathrm{C}$, and after $1 \mathrm{~min}$, it was increased at $15{ }^{\circ} \mathrm{C} / \mathrm{min}$ until $200{ }^{\circ} \mathrm{C}$. Subsequently, the temperature was increased at $5{ }^{\circ} \mathrm{C} / \mathrm{min}$ until $310^{\circ} \mathrm{C}$ and held constant for $10 \mathrm{~min}$. The higher heating value (HHV) in biooil was determined in a bomb calorimeter (Gallenkamp Ballistic Bomb Calorimeters), using benzoic acid as a standard substance. On the other hand, the HHV of the LEM was calculated on the basis of the elemental composition of the biomass using Dulong's formula as described in Vardon et al. ${ }^{9}$ due to the high content of ashes in the LEM. The ammonia nitrogen $\left(\mathrm{NH}_{3}-\mathrm{N}\right)$, nitrate nitrogen $\left(\mathrm{NO}_{3}-\mathrm{N}\right)$, nitrite nitrogen $\left(\mathrm{NO}_{2}-\mathrm{N}\right)$, phosphate phosphorus $\left(\mathrm{PO}_{4}-\mathrm{P}\right)$, and chemical oxygen demand (COD) were measured in the aqueous phase prior to the microalgae cultivation, using a HI-83099-02 bench photometer and following the procedures described in the user's manual (Hanna Instruments, 2014). The total nitrogen (TN), total carbon (TC), and total inorganic carbon (TIC) were determined in a Multi NC 3100 (Analytic Jena) analyzer. The gas-phase composition was analyzed using the method for the biogas analysis described in Caporgno et al. ${ }^{19}$

Carbon, hydrogen, and nitrogen contents in the LEM, the bio-oil, and the solid waste recovered after HTL have been analyzed in an LECO TruSpec elemental analyzer. Oxygen content was determined by difference.

In the cultivation experiments, cell growth was monitored by measuring the absorbance at $750 \mathrm{~nm}$ with a microplate reader (Infinite M200 PRO, Tecan).

Anaerobic Digestion. The batch reactors were set up following the procedure described in Caporgno et al. ${ }^{19}$ The substrate depended on the experiment. The effects of washing the LEM and the SIR variation were simultaneously evaluated. In the washing step, $20 \mathrm{~g}$ of LEM was mixed with $200 \mathrm{~mL}$ of deionized water at room temperature, stirred 20 $\mathrm{min}$, and then centrifuged to recover the solid fraction; the procedure was repeated three times. Reactors with SIRs of 1:4, 1:2, and 1:1 $\mathrm{VS}_{\text {Substrate }}: \mathrm{VS}_{\text {Inoculum }}$ were prepared with different amounts of LEM, either washed or unwashed.

In the codigestion experiments, the SIR was of $1: 2$ $\mathrm{VS}_{\text {Substrate }}: \mathrm{VS}_{\text {Inoculum. }}$. Different mixtures of sewage sludge and unwashed LEM were fed, replacing $25 \%, 50 \%$, and $75 \%$ of the VS from LEM by VS from sewage sludge.

Two different pretreatment methods were applied to unwashed LEM. The first one, ultrasonic pretreatment, consisted of applying three different energy levels: 28,48 , and $55 \mathrm{MJ} / \mathrm{kg}_{\mathrm{TS}}$ at $24 \mathrm{kHz}$ working frequency and $93 \mathrm{~W}$ ultrasonic power (UP200S Hielscher Ultrasonics $\mathrm{GmbH}$, Germany). The LEM were suspended in deionized water for the pretreatment. The pretreatment was carried out at room temperature and with a water bath to avoid the sample heating. The energy supplied was calculated according to the ultrasonic power, the concentration of solids in the sample, and the 
treatment duration. The second pretreatment consisted of combining the addition of alkali and ultrasound application at a low-energy level. The energy applied during ultrasonic disintegration was $17 \mathrm{MJ} / \mathrm{kg}_{\mathrm{TS}}$. The alkali pretreatment consisted of adjusting the $\mathrm{pH}$ at 9,11 , and 13 with $\mathrm{NaOH}$, and keeping the samples at room temperature for $24 \mathrm{~h}$ before digestion. For the pretreatment combination, the $\mathrm{pH}$ in the samples was first adjusted at 9, 11 and 13, and then the ultrasonic disintegration was applied. The $\mathrm{pH}$ in the pretreated samples was neutralized to $\mathrm{pH} 7$ with $\mathrm{HCl}$.

Hydrothermal Liquefaction. The experiments were performed at $300{ }^{\circ} \mathrm{C}, \approx 10 \mathrm{MPa}, 30 \mathrm{~min}$ retention time in a $1 \mathrm{~L}$ reactor $(1 \mathrm{~L} \mathrm{EZE}-$ Seal Bolted Closure, Autoclave Engineers). The reactor was loaded with $300 \mathrm{~g}$ of slurry, containing $20 \%$ LEM in water (w/w), and then purged with nitrogen to remove the oxygen before heating. The different product fractions were recovered (Figure 2) and analyzed.

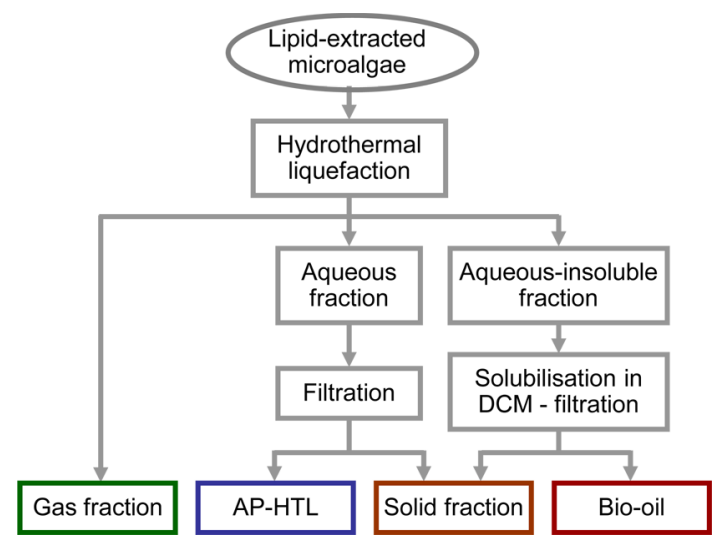

Figure 2. Procedure for the separation of the different products fraction from HTL.

After the reactor was cooled down to room temperature, the gases were vented off and collected in gas sampling bags for further analysis. The major part of AP-HTL was removed by pouring it into a beaker. Dichloromethane (DCM) was used as solvent to recover the bio-oil, which was adhered to the reactor walls. The DCM containing the biooil was separated from the remaining aqueous fraction using a separatory funnel. Both AP-HTL and DCM were vacuum-filtered through preweighted filters for the quantification of the amount of suspended solids. DCM was dried under anhydrous sodium sulfate and evaporated in a rotary evaporator to determine the amount of bio-oil. The AP-HTL was recovered and used for microalgae cultivation.

For the mass balance, the product yields were defined as weight percentages relative to the raw material. The bio-oil yield accounted for the DCM-soluble fraction, and the AP-HTL accounted for dissolved constituents remaining after the DCM extraction. The solid fraction accounted for the mass of dried particulates that were retained after filtration, and finally, the gas-phase yield was calculated by the difference.

Nutrient Recycling. A growth experiment was performed to evaluate the feasibility of replacing the nitrogen source in the algal culture medium by the aqueous phase from HTL. $N$ gaditana was cultivated in culture media containing different proportions of APHTL. Blank assays were performed with seawater enriched with a modification of Guillard's $f / 2$ formulation. ${ }^{20}$ Since $f / 2$ is a rather diluted medium for biomass production purposes, nitrogen and phosphorus concentrations in this modified medium $\left(\mathrm{f} / 2^{+}\right)$were increased up to $60 \mathrm{mg} \mathrm{N}-\mathrm{NO}_{3} / \mathrm{L}$ and to reach a molar N:P ratio equal to $16: 1$. On the basis of the total nitrogen in AP-HTL, five different mixtures of AP-HTL and $\mathrm{f} / 2^{+}$were prepared by the replacement of 7 , $15,30,45$, and $60 \mathrm{mg} \mathrm{N} / \mathrm{L}$ in the $\mathrm{f} / 2^{+}$medium by the AP-HTL addition. Media were filter sterilized through $0.2 \mu \mathrm{m}$.

Microalgae were cultured in sterile 6-well microplates, with a working volume of $3 \mathrm{~mL}$ per well and an initial microalgae density of 3 $\times 10^{5}$ cells $/ \mathrm{mL}$. Triplicate cultures were grown in continuous agitation at $25 \pm 1{ }^{\circ} \mathrm{C}$, under an irradiance of ca. $115 \mu \mathrm{mol}$ photons $/ \mathrm{m}^{2} \mathrm{~s}$ at the surface of the microplates, provided by daylight fluorescent lamps in a 16:8 light:dark cycle.

Microalgae growth was daily monitored by light absorbance measurements, at $750 \mathrm{~nm}$, with a M200Pro Infinite Tecan microplate reader. Division rates $(k)$ were obtained by calculating the slope of the linear least-squares regression for the $\log _{2}$-transformed values of the sample absorbance at $750 \mathrm{~nm}$ during the exponential-growth phase. ${ }^{21}$

\section{RESULTS AND DISCUSSION}

Anaerobic Digestion. Table 1 summarizes the ultimate methane productions obtained in all the digestion experiments,

Table 1. Ultimate Methane Production from LEM with Batch Reactors at $33^{\circ} \mathrm{C}$ and 29 Days Digestion ${ }^{a}$

\begin{tabular}{|c|c|c|c|}
\hline expt & substrate & SIR & $\mathrm{CH}_{4} \mathrm{~mL}_{\mathrm{CH} 4} / \mathrm{g}_{\mathrm{Vs}}$ \\
\hline \multirow[t]{6}{*}{ effect of washing } & unwashed LEM & $1: 4$ & $269 \pm 6$ \\
\hline & & $1: 2$ & $268 \pm 17$ \\
\hline & & $1: 1$ & $273 \pm 6$ \\
\hline & washed LEM & $1: 4$ & $192 \pm 16$ \\
\hline & & $1: 2$ & $185 \pm 9$ \\
\hline & & $1: 1$ & $180 \pm 11$ \\
\hline \multirow[t]{5}{*}{ Aco-D } & LEM & $1: 2$ & $274 \pm 4$ \\
\hline & $25 \%$ sludge & $1: 2$ & $293 \pm 3$ \\
\hline & $50 \%$ sludge & $1: 2$ & $319 \pm 4$ \\
\hline & $75 \%$ sludge & $1: 2$ & $345 \pm 10$ \\
\hline & $100 \%$ sludge & $1: 2$ & $360 \pm 12$ \\
\hline \multirow[t]{4}{*}{ ultrasonic pretreatment } & LEM & $1: 2$ & $274 \pm 4$ \\
\hline & $28 \mathrm{MJ} / \mathrm{kg}_{\mathrm{TS}}$ & $1: 2$ & $269 \pm 7$ \\
\hline & $48 \mathrm{MJ} / \mathrm{kg}_{\mathrm{TS}}$ & $1: 2$ & $299 \pm 6$ \\
\hline & $55 \mathrm{MJ} / \mathrm{kg}_{\mathrm{TS}}$ & $1: 2$ & $294 \pm 4$ \\
\hline \multirow{8}{*}{$\begin{array}{l}\text { combined pretreatment: } \\
\text { US and } \mathrm{NaOH}\end{array}$} & LEM & $1: 2$ & $286 \pm 8$ \\
\hline & $17 \mathrm{MJ} / \mathrm{kg}_{\mathrm{TS}}$ & $1: 2$ & $289 \pm 3$ \\
\hline & $\mathrm{pH} 9$ & $1: 2$ & $309 \pm 6$ \\
\hline & $\mathrm{pH} 11$ & $1: 2$ & $300 \pm 9$ \\
\hline & $\mathrm{pH} 13$ & $1: 2$ & $290 \pm 5$ \\
\hline & $\mathrm{US}+\mathrm{pH} 9$ & $1: 2$ & $290 \pm 3$ \\
\hline & $\mathrm{US}+\mathrm{pH} 11^{b}$ & $1: 2$ & $244 \pm 4$ \\
\hline & $\mathrm{US}+\mathrm{pH} 13$ & $1: 2$ & $296 \pm 3$ \\
\hline
\end{tabular}

${ }^{a}$ These experiments were not done simultaneously; thus, the methane production from LEM samples differs in some of the experiments. ${ }^{b}$ Experimental error confirmed by analysis at the end of the experiment.

the kind of substrate fed, and the SIR used in the reactors. It is worth mentioning that the experiments were not performed simultaneously; therefore, the methane productions from LEM slightly differ in some of the experiments.

LEM Washing and SIR Variation. The ultimate methane productions from washed and unwashed LEM indicated that the washing influenced the $\mathrm{AD}$ negatively. The methane production decreased between $29 \%$ and $34 \%$ after washing. The salt concentration in marine microalgae can strongly affect the methane production; ${ }^{15}$ however, the washing removed not only salts from the biomass. The analysis of the washing water revealed that $67 \pm 1 \%$ of the solid fraction removed was constituted by organic compounds. The loss of these organics caused the significant reduction in the methane production. ${ }^{22}$ Moreover, not only was the organic fraction content affected, but the characteristics of the organic fraction were as well. As mentioned, the same amount of substrate on the VS basis was fed in all the reactors. For this reason, the lower methane 
production cannot be attributed to the organic fraction content in the digesters. Easily biodegradable compounds were removed by washing, thus decreasing the methane production from washed substrates.

Regarding the SIR, it was clearly demonstrated that the evaluated ratios cause no influence on the digestion of washed and unwashed LEM (Table 1). The differences in the ultimate methane production from washed LEM were less than $7 \%$, and from unwashed LEM, less than $2 \%$. In the literature, $1: 1$ is commonly considered an SIR threshold for inhibition; however, it depends on the substrate characteristics. Long chain fatty acids, hydrolysis products of lipids, lead to inhibition during the $\mathrm{AD}$ of microalgae with high lipid content. For this reason, the SIR can be increased in the digesters with LEM. ${ }^{23}$ Similarly, substrates characterized by high protein content cause inhibition by ammonia during $\mathrm{AD} .{ }^{3}$ Ammonia is the most probable cause of inhibition due to the high protein content in the LEM. The ammonia concentration, VFA concentration, and $\mathrm{pH}$ among other parameters indicated stable operation.

In reactors with unwashed LEM, the methane production throughout the first days of the experiment was affected (data not shown). These effects, observed at 1:1, were also reported during the $\mathrm{AD}$ of other $\mathrm{LEM}^{23,24}$ The VFAs were not simultaneously converted into methane, leading to significant accumulation of VFA and methane production decrease. The VFA accumulation can lead to inhibition; however, the VFAs accumulated but they were converted into methane soon afterward. The ratio 1:1 was close to the SIR threshold for inhibition. Regarding the washed LEM, the phenomenon did not occur due to the low degradability of the organic fraction.

LEM Codigestion with Sewage Sludge. The ultimate methane production from LEM and sewage sludge codigestion indicated no synergy by both substrates being mixed. The sewage sludge and the LEM produced the highest and the lowest methane yields, $360 \pm 12 \mathrm{~mL}_{\mathrm{CH} 4} / \mathrm{g}_{\mathrm{Vs}}$ and $274 \pm 4$ $\mathrm{mL}_{\mathrm{CH} 4} / \mathrm{g}_{\mathrm{VS}}$, respectively. The methane productions from the mixtures were proportional to the percentage of each substrate in the mixture. Similar results were reported by Neumann et al., who highlighted that the absence of inhibition allows mixing both substrates without affecting the process operation. ${ }^{25}$ The codigestion with sewage sludge is even more advantageous when considering the nonused capacity of the digesters in WWTP, approximately $30 \% .{ }^{4}$ Recently, Astals et al. emphasized the benefits of integrating pig manure processing and microalgae cultivation, in spite of the absence of synergy in Aco-D. ${ }^{6}$

LEM Pretreatment. The effects of the ultrasonic pretreatment on the $\mathrm{AD}$ of LEM can be observed in Table 1 . The lowest energy input $\left(28 \mathrm{MJ} / \mathrm{kg}_{\mathrm{TS}}\right)$ seemed to be inefficient to increase the LEM degradation, since the methane production was similar to that obtained with untreated LEM. Higher energy inputs (48 and $65 \mathrm{MJ} / \mathrm{kg}_{\mathrm{TS}}$ ) only resulted in a $7-9 \%$ increase in methane production. Similar results were reported after ultrasonic pretreatment of Nannochloropsis sp. LEM. ${ }^{24}$ The results suggest that this pretreatment was probably unsuitable for microalgae wastes from the genus Nannochloropsis, probably due to the cell wall characteristics. The cell wall in the genus Nannochloropsis has a cellulosic inner-wall protected by an outer hydrophobic algaenan layer, ${ }^{26}$ which hampers $\mathrm{AD}$ degradation. ${ }^{27}$ For this reason, powerful pretreatment methods have been suggested for Nannochloropsis species. ${ }^{27}$

In order to improve the limited degradation of the LEM, an ultrasonic pretreatment with low-energy input was combined with alkali addition. For comparison, the effects of alkali and ultrasound were also separately tested. The first visible effects of the pretreatment were noticed in the LEM composition. Alkali treatment caused organic matter destruction in the LEM, so that after the pretreatment with alkali addition up to $\mathrm{pH} 13$ the VS/TS ratio decreased from 0.75 to 0.62 . Likewise, the combined pretreatment decreased the VS/TS ratio down to 0.66. Similar VS/TS decreases reported during the alkali and ultrasonic pretreatment of other substrates were attributed to the mineralization of some components. ${ }^{28}$ Pretreatment with alkali also increased the methane production up to $8 \%$ (Table 1 ), with the highest methane production being obtained with the lowest $\mathrm{NaOH}$ dosage. The pretreatment of undamaged microalgae with similar $\mathrm{NaOH}$ dosages also gave higher methane productions with lower dosages. ${ }^{29}$ Furthermore, the highest methane production was obtained from the nonpretreated microalgae. ${ }^{29}$ Regarding the ultrasonic pretreatment $\left(17 \mathrm{MJ} / \mathrm{kg}_{\mathrm{TS}}\right)$, the methane production remained unchanged, as expected considering the inefficiency of a stronger input (28 $\mathrm{MJ} / \mathrm{kg}_{\mathrm{TS}}$ ) discussed at the beginning of this section. Surprisingly, the pretreatment combination did not increase the methane production (Table 1). References regarding the $\mathrm{AD}$ of LEM are currently scarce, especially those focused on the effects of pretreatments. Only Suresh et al. reported an alkali pretreatment of LEM and its combination with ultrasonication. The authors suggested inhibition due to VFA accumulation, with the methane production negatively affected. ${ }^{30}$ However, in the present work, the absence of inhibition was corroborated in all the reactors at the end of experiments. On the other hand, the combined pretreatment applied to other lignocellulosic substrates did not affect the total methane production. ${ }^{28}$ The alkaline pretreatment affects the intermolecular linkages and functional groups of lignin, cellulose, and hemicellulose. ${ }^{31}$ The cell walls structures are more vulnerable to the shear forces in the ultrasonic pretreatment when the pretreatments are combined. However, the effectiveness of the alkaline pretreatment is considered dependent on the content of lignin in the biomass, and the content of lignin in microalgae is considered low. ${ }^{31}$

Hydrothermal Liquefaction. The mass balance allows establishing the product distribution after the HTL process. The results, presented in Table 2, indicated that similar amounts of the biomass were distributed between the bio-oil, the AP-HTL, the gas, and the solid fraction.

The bio-oil showed the highest yield, $28 \pm 2 \mathrm{~g} / 100 \mathrm{~g}_{\mathrm{LEM}}$. This yield is comparable to that obtained by processing Scenedesmus sp. LEM, with high-protein and low-lipid contents, under the same experimental conditions. ${ }^{9}$ Higher bio-oil yields have been obtained from N. salina LEM, ${ }^{10}$ but with a high amount of residual lipids $\left(\approx 20 \mathrm{~g} / 100 \mathrm{~g}_{\text {sample }}\right)$. Bio-oil yields

Table 2. Mass Balance of HTL and C and N Recovery from the LEM

$\begin{array}{lcccr} & \text { bio-oil } & \text { AP-HTL } & \text { gas } & \begin{array}{c}\text { solid } \\ \text { fraction }\end{array} \\ \text { mass balance }\left(\mathrm{g} / 100 \mathrm{~g}_{\mathrm{LEM}}\right) & 28 \pm 2 & 24 \pm 2 & 27 \pm 3 & 21 \pm 2 \\ \mathrm{C} \text { recovery } & 48 \pm 4 & 26 \pm 1 & 14 \pm 1^{a} & 9 \pm 2 \\ \quad \% \text { of the C in LEM) } & & & & \\ \begin{array}{c}\mathrm{N} \text { recovery } \\ (\% \text { of the } \mathrm{N} \text { in LEM) }\end{array} & 24 \pm 2 & 56 \pm 1 & b & 3 \pm 1\end{array}$

${ }^{a}$ Only the amount of $\mathrm{CO}_{2}$ determined in the gas was considered. ${ }^{b}$ The $\mathrm{N}$ content in gas was not analyzed. 
close to $45 \mathrm{~g} / 100 \mathrm{~g}_{\text {sample }}$ have been recently reported from protein-extracted Scenedesmus $s p .{ }^{11}$ once again, the lipid fraction which remains after extracting the proteins $((\approx 18.5$ $\left.\mathrm{g} / 100 \mathrm{~g}_{\text {sample }}\right)$ may contribute to the high bio-oil yield. Lipids present the highest bio-oil yield, followed by proteins and carbohydrates. ${ }^{12}$ On the other hand, the bio-oil obtained by processing $D$. tertiolecta from $\beta$-carotene production yielded approximately $5 \mathrm{~g} / 100 \mathrm{~g}_{\text {sample }}$ under operating conditions similar to the present experiments; quite severe operating conditions were required to increase the bio-oil yield. ${ }^{7}$ The biooil yields obtained in the experiments here reported are also comparable with that reported in the literature, after processing from the whole Nannochloropsis oculata, in spite of the differences in the lipid content. ${ }^{12}$ It worth mentioning that bio-oil yield was calculated on the dry weight basis of the LEM; the yield increases when is calculated on the dry ash-free basis due to the high content of ashes in the LEM.

Regarding the characteristics of the bio-oil, the analysis of the $\mathrm{HHV}$ resulted in $37.2 \pm 0.9 \mathrm{MJ} / \mathrm{kg}$, which is in agreement with the values reported for other LEM under the same experimental conditions ${ }^{9}$ and other microalgae species under different HTL conditions. ${ }^{8,12}$ The HHV was considerably low for the LEM, $17.7 \pm 0.1 \mathrm{MJ} / \mathrm{kg}$, mainly as a consequence of the high content of ashes in the LEM. The qualitative GC-MS analysis of the bio-oil provided evidence of its complexity. The high protein content in the LEM led to the presence of nitrogenous compounds in the bio-oil. The main compounds can be included in the category of aromatic compounds such as indole derivatives or in the category of highly aliphatic compounds, including long chain alkanes and alkenes, free fatty acids, and amide derivatives. Similar compounds have been also identified by other authors. ${ }^{7,9,11}$ The elemental analysis of the bio-oil determined $\mathrm{C}, \mathrm{H}, \mathrm{N}$, and $\mathrm{O}$ percentages of $70 \%, 9 \%, 5 \%$, and $17 \%$, respectively. According to these results, the bio-oil quality is better than that reported by Vardon et al. ${ }^{9}$ and comparable to the bio-oil quality reported by $\mathrm{Zhu}$ et al. $^{10}$ in terms of $\mathrm{N}$ and $\mathrm{O}$ contents. The elemental analysis of the LEM determined $\mathrm{C}, \mathrm{H}, \mathrm{N}$, and $\mathrm{O}$ percentages of $40 \%, 6 \%, 5 \%$, and $24 \%$, respectively. On the basis of these results, $48 \pm 4 \%$ of the $C$ from the LEM was converted into bio-oil, similar to the value reported by Vardon et al. ${ }^{9}$

The gas yields indicated that a large portion of the initial biomass was converted into gaseous products. Although the gas composition was not analyzed in detail, the chromatogram revealed that the gas fraction was mainly $\mathrm{CO}_{2}$ and small amounts of simple hydrocarbons as it was expected on the basis of the literature. ${ }^{8,11}$ The high content of $\mathrm{CO}_{2}$ suggests the possibility of using the exhausted gas in the microalgae cultivation unit. ${ }^{32}$

The yield of the solid fraction was considerably higher than the yields obtained after processing LEM under similar experimental conditions. ${ }^{9,11}$ Comparable yields of the solid fraction were reported during the HTL of Dunaliella tertiolecta waste, but in this case, the bio-oil yield indicates low biomass conversion. ${ }^{7}$ As mentioned before, the LEM used here was characterized by high ash content, and most of the ashes contributed to increase the yield of the solid fraction. The analysis of the solid fraction revealed the presence of the major part of the inorganic fraction from the LEM, $78 \pm 3 \%$. The elemental analysis of the solid determined $\mathrm{C}, \mathrm{H}, \mathrm{N}$, and $\mathrm{O}$ percentages of $78 \%, 12 \%, 4 \%$, and $6 \%$, respectively. The high percentage of $\mathrm{C}$ and the appearance of the solids suggest the formation of biochar as a consequence of the repolymerization and carbonization of water-soluble compounds derived mainly from carbohydrates, due to the high temperature in the process. ${ }^{33}$ On the basis of the percentages of ashes and $\mathrm{C}$ in the solid fraction, it can be stated that a considerable high biomass conversion was achieved during the process.

The mass balance revealed that the AP-HTL contained a high percentage of the inorganic fraction originally present in the LEM, but also organic compounds. The COD and the

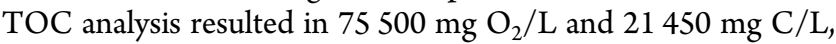
respectively, in agreement with the concentrations reported in the literature. ${ }^{13,34}$ The COD and TOC values indicate the presence of dissolved organic compound. Although the compounds were not identified, they may be formic acid, acetic acid, lactic acid, and glycerol; among others are some polar organic compounds which remained solubilized in water. $^{35}$ As can be seen in Table 2, $26 \pm 1 \%$ of the $C$ from the LEM remained solubilized in the AP-HTL. On the basis of the high protein content, its decomposition can generate nitrogen compounds such as pyroles, indoles, and phenols. ${ }^{12}$ The nitrogen content was approximately $7000 \mathrm{mg} \mathrm{N} / \mathrm{L}$, and around $68 \%$ of the $\mathrm{TN}$ was in the form of $\mathrm{NH}_{4}^{+}$. The major part of the $\mathrm{N}$ from the LEM remained solubilized in the APHTL (Table 2). The $\mathrm{C}$ to $\mathrm{N}$ ratio resulted in $\approx 3.4$ in the aqueous phase, as reported during the HTL of several microalgae species under similar experimental conditions. ${ }^{8,12,14}$

The $\mathrm{PO}_{4}{ }^{3-}$ was $90 \mathrm{mg} \mathrm{P} / \mathrm{L}$, which is considerably low compared with the $\mathrm{N}$ and $\mathrm{C}$ concentrations. The phosphorus distribution in the HTL products can be affected by reaction temperature and retention time, and by the reaction between the amino acids with reducing sugar. ${ }^{13}$

As mentioned before, the optimization of the HTL process was not studied in this work. However, the production of biooil from LEM and the subsequent upgrading process was already reported by Zhu et al. ${ }^{10}$ The similarities in the composition of the biomass and the yields and characteristics of the bio-oil suggest that the HTL of lipid-extracted N. oculata may be also a promising alternative to produce liquid fuels which can compete with conventional fossil-fuels. Moreover, the nutrient recycling can significantly contribute to improve economic aspects.

Nutrient Recycling. The suitability of the AP-HTL for microalgae cultivation was evaluated. According to the nutrient analysis performed, the N:P ratio of the AP-HTL was 78:1. Such a high N:P ratio is far from the optimal N:P ratios for microalgae development; ${ }^{36}$ this was confirmed by the low Nannochloropsis gaditana growth on dilutions of AP-HTL in a previous culture experiment (data not shown). Therefore, it was decided to check the suitability of the AP-HTL only as nitrogen source. With this aim, part or the entire $\mathrm{N}-\mathrm{NO}_{3}$ source of the standard medium was substituted by a volume of APHTL that provided an equal amount of nitrogen. Several APHTL loads were tested considering that a high AP-HTL concentration could have an inhibitory effect on the culture due to toxic compounds such as amides or heterocyclic compounds. $^{13}$

Figure 3 shows $N$. gaditana growth curves for different loads of AP-HTL; the curves are plotted in a semilogarithmic scale for better visualization of the exponential-growth phase. The amount of AP-HTL that accounted for the total substitution of $\mathrm{N}-\mathrm{NO}_{3}$ (HTL60) inhibited growth from the beginning, as evidenced by the reduced division rate (Table 3 ) and the final biomass which was $25 \%$ of that obtained in the standard medium. On the contrary, AP-HTL loads contributing up to 30 


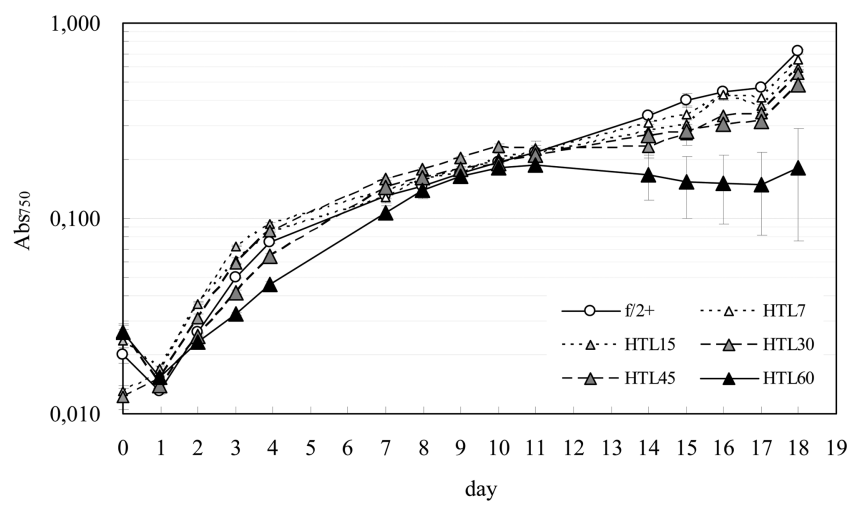

Figure 3. Growth curves in semilogarithmic scale for N. gaditana in several culture media.

mg N (HTL30) supported growths only slightly smaller than those in the standard medium. Division rates were similar or even slightly higher than those in the standard medium, but at the end, final biomass (in terms of $\mathrm{Abs}_{750 \mathrm{~nm}}$ ) was $90-77 \%$ of that obtained in standard medium: the higher the final biomass the lower the AP-HTL load.

The applicability of an AP-HTL as microalgae culture medium depends on the concentration and form of macro(nitrogen, phosphorus, $\mathrm{N}: \mathrm{P}$ ratio) and micronutrients, ${ }^{37}$ the absence of harmful compounds, ${ }^{12,34,38}$ the $\mathrm{pH}^{14}$ and the microalgae species used. ${ }^{12,14}$ In the present experiments, the growth inhibition at HTL60 concentrations may reflect a compound at harmful concentration rather than the form of inorganic $\mathrm{N}$ supplied. Although high amounts of $\mathrm{NH}_{4}^{+}$are known to be toxic, ${ }^{39} N$. gaditana has demonstrated thriving at concentrations up to $190 \mathrm{mg} \mathrm{N}-\mathrm{NH}_{4}^{+} / \mathrm{L}$ when the $\mathrm{pH}$ of the culture is controlled at $8.0{ }^{40}$ Therefore, the $60 \mathrm{mg} \mathrm{N}^{4} \mathrm{NH}_{4}{ }^{+} / \mathrm{L}$ in HTL60 at the initial pH of 8.3 (Table 3) should not be harmful.

The AP-HTL contributing up to $30 \mathrm{mg} \mathrm{N}$ (HTL30) supports growth close to the maximum growth obtained with standard medium. Further experiments are needed to ascertain which other nutrients, such as iron and other micronutrients, can be substituted from standard media by AP-HTL.

\section{CONCLUSIONS}

This study demonstrated that the valorization of the lipidextracted Nannochloropsis can be carried out producing energy and a nitrogen source for biomass cultivation. These methods of valorization can be beneficial for the biodiesel production process, and also for other processes which extract valuable compounds from microalgae. In addition to the possibility of converting the LEM into methane, the codigestion with sewage sludge demonstrated the viability of the codigestion process. The codigestion of LEM and sewage sludge allows taking advantage of the oversized digesters in some WWTPs. The pretreatment of LEM before digestion was unsuitable for microalgae wastes, probably due to the cell wall characteristics which hamper degradation. For this reason, powerful pretreatment methods should be evaluated to increase the biodegradability of the biomass.

Another alternative for LEM valorization is the conversion into bio-oil. The results revealed the possibility to obtain high bio-oil yields. Moreover, recycling the aqueous phase generated during HTL to the microalgae cultivation unit reduces the amount of fertilizers for cultivation. The high nutrient content in the aqueous phase is problematic for water discharge; thus, the microalgae cultivation can contribute to accomplish the regulation for water discharge.

\section{AUTHOR INFORMATION}

\section{Corresponding Author}

*E-mail: christophe.bengoa@urv.cat. Phone: +34 977558619.

\section{Notes}

The authors declare no competing financial interest.

\section{ACKNOWLEDGMENTS}

M.P.C. thanks the Spanish Ministerio de Educación, Cultura y Deporte, for his predoctoral scholarship (ref AP2012-3726). Financial support for this research was provided by the Spanish Ministerio de Educación y Ciencia and FEDER, Project CTM2011-23069, and Project CTQ2014-56285-R "Cultivo, concentración, fraccionamiento y obtención de producto en refineria de microalgas" funded by the Spanish Ministerio de Economia y Competitividad. The authors thank Gestió Ambiental i Abastament S.A. Company (WWTP of Reus, Spain) for their kind collaboration during the project.

\section{REFERENCES}

(1) Pragya, N.; Pandey, K. K.; Sahoo, P. K. A review on harvesting, oil extraction and biofuels production technologies from microalgae. Renewable Sustainable Energy Rev. 2013, 24, 159-171.

(2) Rawat, I.; Ranjith Kumar, R.; Mutanda, T.; Bux, F. Biodiesel from microalgae: A critical evaluation from laboratory to large scale production. Appl. Energy 2013, 103, 444-467.

(3) Caporgno, M. P.; Bengoa, C. Anaerobic digestion of microalgae: the benefits of digesting microalgae waste. Curr. Biochem. Eng. 2016, in press.

(4) Mata-Alvarez, J.; Dosta, J.; Romero-Güiza, M. S.; Fonoll, X.; Peces, M.; Astals, S. A critical review on anaerobic co-digestion achievements between 2010 and 2013. Renewable Sustainable Energy Rev. 2014, 36, 412-427.

(5) Caporgno, M. P.; Taleb, A.; Olkiewicz, M.; Font, J.; Pruvost, J.; Legrand, J.; Bengoa, C. Microalgae cultivation in urban wastewater:

Table 3. $\mathbf{N}$ Source in the Culture Media and Summarized Results Obtained During Cultivation

\begin{tabular}{|c|c|c|c|c|c|c|c|}
\hline & & \multicolumn{6}{|c|}{ Media } \\
\hline & & $\mathrm{f} / 2^{+}$ & HTL7 & HTL15 & HTL30 & HTL45 & HTL60 \\
\hline \multirow[t]{3}{*}{ source of $\mathrm{N}(\mathrm{mg} \mathrm{N} / \mathrm{L})$} & $\mathrm{NO}_{3}^{-}$from $\mathrm{f} / 2^{+}$ & 60 & 53 & 45 & 30 & 15 & 0 \\
\hline & $\mathrm{NH}_{4}^{+}$from AP-HTL ${ }^{a}$ & 0 & 7 & 15 & 30 & 45 & 60 \\
\hline & total inorganic $\mathrm{N}$ & 60 & 60 & 60 & 60 & 60 & 60 \\
\hline$k$ (duplications/day) & & $0.95 \pm 0.03$ & $0.97 \pm 0.11$ & $1.04 \pm 0.02$ & $0.97 \pm 0.07$ & $0.79 \pm 0.02$ & $0.54 \pm 0.02$ \\
\hline initial $\mathrm{pH}$ & & 8.1 & 7.4 & 7.8 & 8.3 & 8.2 & 8.3 \\
\hline final $\mathrm{pH}$ & & $9.8 \pm 0.1$ & $9.7 \pm 0.1$ & $9.9 \pm 0.0$ & $9.6 \pm 0.0$ & $9.1 \pm 0.0$ & $7.8 \pm 0.1$ \\
\hline
\end{tabular}

${ }^{a}$ The amount of $\mathrm{NO}_{3}{ }^{-}$was negligible in the AP-HTL. 
nutrient removal and biomass production for biodiesel and methane. Algal Res. 2015, 10, 232-239.

(6) Astals, S.; Musenze, R. S.; Bai, X.; Tannock, S.; Tait, S.; Pratt, S.; Jensen, P. D. Anaerobic co-digestion of pig manure and algae: Impact of intracellular algal products recovery on co-digestion performance. Bioresour. Technol. 2015, 181, 97-104.

(7) Shuping, Z.; Yulong, W.; Mingde, Y.; Kaleem, I.; Chun, L.; Tong, $\mathrm{J}$. Production and characterization of bio-oil from hydrothermal liquefaction of microalgae Dunaliella tertiolecta cake. Energy 2010, 35, 5406-5411.

(8) Jena, U.; Das, K. C.; Kastner, J. R. Effect of operating conditions of thermochemical liquefaction on biocrude production from Spirulina platensis. Bioresour. Technol. 2011, 102, 6221-6229.

(9) Vardon, D. R.; Sharma, B. K.; Blazina, G. V.; Rajagopalan, K.; Strathmann, T. J. Thermochemical conversion of raw and defatted algal biomass via hydrothermal liquefaction and slow pyrolysis. Bioresour. Technol. 2012, 109, 178-187.

(10) Zhu, Y.; Albrecht, K. O.; Elliott, D. C.; Hallen, R. T.; Jones, S. B. Development of hydrothermal liquefaction and upgrading technologies for lipid-extracted algae conversion to liquid fuels. Algal Res. 2013, 2, 455-464.

(11) Audo, M.; Paraschiv, M.; Queffélec, C.; Louvet, I.; Hémez, J.; Fayon, F.; Lépine, O.; Legrand, J.; Tazerout, M.; Chailleux, E.; Bujoli, B. Subcritical hydrothermal liquefaction of microalgae residues as a green route to alternative road binders. ACS Sustainable Chem. Eng. 2015, 3, 583-590.

(12) Biller, P.; Ross, A. B.; Skill, S. C.; Lea-Langton, A.; Balasundaram, B.; Hall, C.; Riley, R; Llewellyn, C. A. Nutrient recycling of aqueous phase for microalgae cultivation from the hydrothermal liquefaction process. Algal Res. 2012, 1, 70-76.

(13) Gai, C.; Zhang, Y.; Chen, W. T.; Zhou, Y.; Schideman, L.; Zhang, P.; Tommaso, G.; Kuo, C. T.; Dong, Y. Characterization of aqueous phase from the hydrothermal liquefaction of Chlorella pyrenoidosa. Bioresour. Technol. 2015, 184, 328-335.

(14) López-Barreiro, D.; Bauer, M.; Hornung, U.; Posten, C.; Kruse, A.; Prins, W. Cultivation of microalgae with recovered nutrients after hydrothermal liquefaction. Algal Res. 2015, 9, 99-106.

(15) Lakaniemi, A. M.; Hulatt, C. J.; Thomas, D. N.; Tuovinen, O. H.; Puhakka, J. A. Biogenic hydrogen and methane production from Chlorella vulgaris and Dunaliella tertiolecta biomass. Biotechnol. Biofuels 2011, 4, 34-46.

(16) Passos, F.; Astals, S.; Ferrer, I. Anaerobic digestion of microalgal biomass after ultrasound pre-treatment. Waste Manage. 2014, 34, 2098-2103.

(17) Kim, D. H.; Jeong, E.; Oh, S. E.; Shin, H. S. Combined (alkaline + ultrasonic) pretreatment effect on sewage sludge disintegration. Water Res. 2010, 44, 3093-3100.

(18) Wang, Y. Z.; Chen, X.; Wang, Z.; Zhao, J. F.; Fan, T. T.; Li, D. S.; Wang, J. H. Effect of low concentration alkali and ultrasound combination pretreatment on biogas production by stalk. Adv. Mater. Res. 2011, 383-390, 3434-3437.

(19) Caporgno, M. P.; Trobajo, R.; Caiola, N.; Ibáñez, C.; Fabregat, A.; Bengoa, C. Biogas production from sewage sludge and microalgae co-digestion under mesophilic and thermophilic conditions. Renewable Energy 2015, 75, 374-380.

(20) Guillard, R. R. L. Culture of phytoplankton for feeding marine invertebrates. In Culture of Marine Invertebrate Animals; Smith, W. L., Chanley, M. H., Eds.; Plenum Press: New York, 1975.

(21) Andersen, R. A. Algal Culturing Techniques, 1st Ed.; Elsevier Academic Press: San Diego, CA, 2005.

(22) Kinnunen, H. V.; Koskinen, P. E. P.; Rintala, J. Mesophilic and thermophilic anaerobic laboratory-scale digestion of Nannochloropsis microalga residues. Bioresour. Technol. 2014, 155, 314-322.

(23) Zhao, B.; Ma, J.; Zhao, Q.; Laurens, L.; Jarvis, E.; Chen, S.; Frear, C. Efficient anaerobic digestion of whole microalgae and lipidextracted microalgae residues for methane energy production. Bioresour. Technol. 2014, 161, 423-430.
(24) Alzate, M. E.; Muñoz, R.; Rogalla, F.; Fernandez-Polanco, F.; Pérez-Elvira, S. I. Biochemical methane potential of microalgae biomass after lipid extraction. Chem. Eng. J. 2014, 243, 405-410.

(25) Neumann, P.; Torres, A.; Fermoso, F. G.; Borja, R.; Jeison, D. Anaerobic co-digestion of lipid-spent microalgae with waste activated sludge and glycerol in batch mode. Int. Biodeterior. Biodegrad. 2015, $100,85-88$

(26) Scholz, M. J.; Weiss, T. L.; Jinkerson, R. E.; Jing, J.; Roth, R.; Goodenough, U.; Posewitz, M. C.; Gerken, H. G. Ultrastructure and composition of the Nannochloropsis gaditana cell wall. Eukaryotic Cell 2014, 13, 1450-1464.

(27) Bohutskyi, P.; Betenbaugh, M. J.; Bouwer, E. J. The effects of alternative pretreatment strategies on anaerobic digestion and methane production from different algal strains. Bioresour. Technol. 2014, 155, $366-372$.

(28) Park, N. D.; Helle, S. S.; Thring, R. W. Combined alkaline and ultrasound pre-treatment of thickened pulp mill waste activated sludge for improved anaerobic digestion. Biomass Bioenergy 2012, 46, 750756.

(29) Cho, S.; Park, S.; Seon, J.; Yu, J.; Lee, T. Evaluation of thermal, ultrasonic and alkali pretreatments on mixed-microalgal biomass to enhance anaerobic methane production. Bioresour. Technol. 2013, 143, 330-336.

(30) Suresh, A.; Seo, C.; Chang, H. N.; Kim, Y. C. Improved volatile fatty acid and biomethane production from lipid removed microalgal residue $(\mathrm{LR} \mu \mathrm{AR})$ through pre-treatment. Bioresour. Technol. 2013, 149, 590-594.

(31) Zheng, Y.; Zhao, J.; Xu, F.; Li, Y. Pretreatment of lignocellulosic biomass for enhanced biogas production. Prog. Energy Combust. Sci. 2014, 42, 35-53.

(32) López-Barreiro, D.; Prins, W.; Ronsse, F.; Brilman, W. Hydrothermal liquefaction (HTL) of microalgae for biofuel production: State of the art review and future prospects. Biomass Bioenergy 2013, 53, 113-127.

(33) Yang, W.; Li, X.; Li, Z.; Tong, C.; Feng, L. Understanding lowlipid algae hydrothermal liquefaction characteristics and pathways through hydrothermal liquefaction of algal major components: Crude polysaccharides, crude proteins and their binary mixtures. Bioresour. Technol. 2015, 196, 99-108.

(34) Jena, U.; Vaidyanathan, N.; Chinnasamy, S.; Das, K. C. Evaluation of microalgae cultivation using recovered aqueous coproduct from thermochemical liquefaction of algal biomass. Bioresour. Technol. 2011, 102, 3380-3387.

(35) Biller, P.; Ross, A. B. Potential yields and properties of oil from the hydrothermal liquefaction of microalgae with different biochemical content. Bioresour. Technol. 2011, 102, 215-225.

(36) Klausmeier, C. A.; Litchman, E.; Daufresne, T.; Levin, S. A. Optimal nitrogen-to-phosphorus stoichiometry of phytoplankton. Nature 2004, 429, 171-174.

(37) Garcia-Alba, L.; Torri, C.; Fabbri, D.; Kersten, S. R. A.; Brilman, D. W. F. Microalgae growth on the aqueous phase from hydrothermal liquefaction of the same microalgae. Chem. Eng. J. 2013, 228, 214-223.

(38) Selvaratnam, T.; Pegallapati, A. K.; Reddy, H.; Kanapathipillai, N.; Nirmalakhandan, N.; Deng, S.; Lammers, P. J. Algal biofuels from urban wastewaters: Maximizing biomass yield using nutrients recycled from hydrothermal processing of biomass. Bioresour. Technol. 2015, $182,232-238$.

(39) Collos, Y.; Harrison, P. J. Acclimation and toxicity of high ammonium concentrations to unicellular algae. Mar. Pollut. Bull. 2014, $80,8-23$.

(40) Sepúlveda, C.; Acién, F. G.; Gómez, C.; Jiménez-Ruíz, N.; Riquelme, C.; Molina-Grima, E. Utilization of centrate for the production of the marine microalgae Nannochloropsis gaditana. Algal Res. 2015, 9, 107-116. 